\title{
Inteligentne wyzwania technologii i organizacji procesów wytwarzania maszyn
}

\author{
Dr hab. inż. Joanna Kałkowska \\ Politechnika Poznańska, Wydział Inżynierii Zarządzania \\ Instytut Zarządzania i Systemów Informacyjnych
}

\section{Wprowadzenie}

Celem artykułu jest heurystyczna (metody delficka i burza mózgów) egzemplifikacja tytułowych wyzwań, przed którymi staną w niedalekiej przyszłości technologia i organizacja wytwarzania maszyn, oparte na wymogu korzystania z metod sztucznej inteligencji. Stanowią one źródło następujących narzędzi koncepcji Przemysłu 4.0 (rysunek 1): integracji systemu (System Integration), analizy dużych zbiorów danych (Big Data), Internetu rzeczy (Internet of Things), wytwarzania addytywnego (Additive Manufacturing), chmury obliczeniowej (Cloud Computing), autonomicznych robotów (Autonomous Robots), rzeczywistości rozszerzonej ( $A u$ gmented Reality) i cyberbezpieczeństwa (Cybersecurity).

Prezentowane $\mathrm{w}$ artykule badania terenowe o charakterze studium przypadku dotyczą przemysłowej praktyki przepływowych procesów wytwarzania (montażowe linie produkcyjne o ustalonych marszrutach). Obiektem badań są procesy wytwarzania dwóch rodzajów pojazdów transportu publicznego: mikrobusów (względnie stacjonarne stanowiska robocze) i autobusów (mobilne brygady montażowe).

Skuteczność (a więc działanie z powodzeniem, czyli ukierunkowanie na biznesowy sukces zapewniający wytwórcy przetrwanie i rozwój) oraz sprawność (działania polegające na gospodarowaniu zasobami przedsiębiorstwa mądrze i bez zbędnego marnotrawstwa) są dla współczesnej technologii i organizacji procesów wytwarzania wspomnianych maszyn wyzwaniem elementarnym. Obserwuje się to w warunkach zaskakującej oraz narastającej turbulencji i nieprzewidywalności zmian otoczenia przedsiębiorstwa, a także w różnych wymiarach tej zmienności: technologicznym, organizacyjnym, ekonomicznym, społecznym i politycznym. 


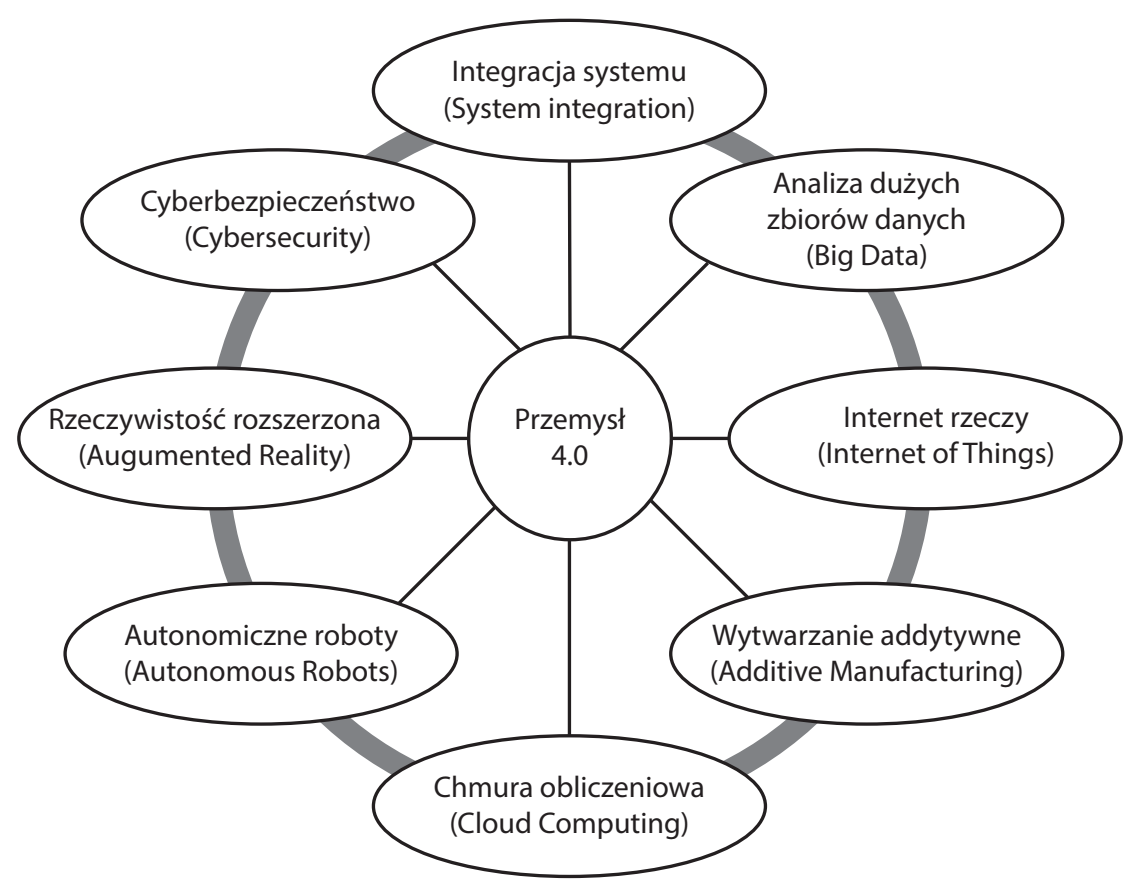

Rysunek 1. Narzędzia koncepcji Przemystu 4.0

Źródło: opracowanie własne na podstawie W. Sugalski, Przemysł 4.0, PWC Polska, Warszawa 2018.

Syntezą opisującą turbulentną i zmienną współczesność otoczenia dzisiejszego wytwórcy maszyn są następujące fakty:

- zmiany w otoczeniu przedsiębiorstwa coraz częściej mają charakter dyskontynuacyjny, w związku z czym wcześniejsze doświadczenia stają się coraz mniej przydatne (rośnie stopień nowości zmian);

- przedsiębiorstwa zmuszane są do poświęcania coraz większych zasobów własnych na utrzymywanie kontaktów marketingowych i innowacyjnych ze swoim otoczeniem;

- rośnie intensywność skracania się czasu od pojawienia się określonej innowacji (technologii) do jej komercjalizacji;

- rozmywa się granica między otoczeniem a przedsiębiorstwem oraz interakcyjny i synergiczny wpływ różnorodnych czynników zewnętrznych na dziedzinę działalności wytwórczej przedsiębiorstwa.

Powyższe fakty stanowią podstawowe uzasadnienie podjęcia tytułowego problemu inteligentnych wyzwań, przed którymi staną w niedalekiej przyszłości technologia i organizacja wytwarzania maszyn.

1 H.I. Ansoff, Zarzqdzanie strategiczne, Polskie Wydawnictwo Ekonomiczne, Warszawa 1985. 


\section{Elastyczność i zwinność technologii i organizacji procesów wytwarzania maszyn}

Ponieważ zmienność i nieprzewidywalność otoczenia narastają i nic nie wskazuje na to, że trend ten się odwróci ${ }^{2}$, współczesne przedsiębiorstwa produkujące pojazdy transportu publicznego, opierając się na liniach technologicznych o obciążeniu stałym (tak zwana technologia i organizacja sztywna, zakładająca stabilność otoczenia), są - w sytuacji skracania cyklu życia technologii i organizacji, różnicowania potrzeb odbiorców i zmienności popytu - z góry skazane na porażkę. Przedsiębiorstwa tego typu mogą jednak trwać, a nawet rozwijać się w warunkach zmienności i nieprzewidywalności otoczenia, o ile zawczasu podejmą działania określane mianem inteligencji strategicznej. Polegają one na przedkładaniu nad zasobność materialną zarówno zasobów wiedzy o nowych rynkach i nowych technologiach, organizacji wytwarzania, jak i zasobów finansowych umożliwiających nabycie tych technologii. W podobnej sytuacji, aczkolwiek o wiele korzystniejszej w porównaniu z tak zwaną sztywną technologią i organizacją wytwarzania, znajdują się ci wytwórcy pojazdów transportu publicznego, którzy dysponują wyposażeniem uniwersalnym, umożliwiającym pewnego rodzaju elastyczność asortymentową produkowanych pojazdów. Należy jednak zwrócić uwagę, że wydajność i produktywność systemów uniwersalnych jest niższa niż technologii i organizacji sztywnych, ale związane z tym wariantem wytwarzania ryzyko biznesowe, powodowane turbulencjami otoczenia, jest mniejsze. Oczywiście i w tym wariancie wytwarzania zalecane jest podejmowanie opisanych działań, określanych mianem inteligencji strategicznej3.

Trzeci wariant produkcyjnego wytwarzania pojazdów transportowych określany bywa mianem technologii i organizacji elastycznej, a więc takiej, która umożliwia łatwe i szybkie przezbrajanie oraz zmianę programów (sterowanych numerycznie i komputerowo) maszyn i urządzeń realizujących procesy wytwarzania, opierając się na elastycznych gniazdach i liniach produkcyjnych. Wariant ten ${ }^{4}$ zapewnia większą produktywność i wydajność, jednak jest to okupione większym ryzykiem biznesowym (wyższy poziom kosztów stałych i gorsza rentowność w przypadku niewykorzystania aktywów trwałych).

Elastyczność technologii i organizacji procesów wytwarzania maszyn pozwala producentom pojazdów transportu publicznego rozpoznawać zmienność

2 S. Trzcieliński, Zwinne przedsiębiorstwo, Wydawnictwo Politechniki Poznańskiej, Poznań 2011.

3 S. Trzcieliński, Lean management a wirtualność przedsiębiorstwa, „Prace Naukowe Instytutu Organizacji i Zarządzania Politechniki Wroctawskiej” 2003, t. 73, nr 23.

4

S. Trzcieliński, Zwinne... 
i nieprzewidywalność otoczenia jako okoliczność sprzyjającą, a nie wrogą biznesowym celom współczesnego przed siębiorstwa ${ }^{5}$. Warunki prowadzenia biznesu przesunęły się bowiem z modelu zmian „leniwych i ciągłych” do modelu zmian „dynamicznych i skokowych"6. Zgodnie z teorią chaosu w zmiennym otoczeniu „nie można uzyskać zadowalających wyników ani przez ukierunkowanie na zamierzone cele, ani też za pomocą szczegółowo zaplanowanych sposobów ich osiągnięcia. Sukces odnoszą te firmy, które potrafią wykorzystać pojawiające się okazje"7. Modelowe i konceptualne rozwinięcia takiego podejścia zapoczątkowała publikacja $21^{\text {st }}$ Century manufacturing enterprise strategy: an industry-led view ${ }^{8}, \mathrm{w}$ której wprowadzone zostało pojęcie agility („zwinność”), odniesione zarówno do procesów wytwarzania, jak i do przedsiębiorstwa.

Zwinność zdefiniowana została jako zdolność do odnoszenia sukcesów w otoczeniu przedsiębiorstwa, w którym ciągle zachodzą nieprzewidywalne zmiany stwarzające okazje rynkowe ${ }^{9}$. Istotą zwinności procesów wytwarzania jest ich ukierunkowanie na wykorzystywanie okazji rynkowych, które pojawiają się właśnie

5 A.K. Sethi, S.P. Sethi, Flexibility in Manufacturing: A survey, „The International Journal of Flexible Manufacturing Systems" 1990, no. 2, s. 289-328; S.L. Goldman, R.N. Nagel, Management, technology and agility: the Emergence of a new era in manufacturing, „International Journal of Technology Management" 1993, no. 8, s. 18-38; Z. Zhang, H. Sharifi, A methodology for achieving agility in manufacturing organizations, „International Journal of Operations and Production Management" 2000, vol. 20, no. 4.

6 B. Nogalski, Wybór paradygmatów zarzq̨dzania przedsiębiorstwem przyszłości, [w:] I.K. Hejduk (red.), Przedsiębiorstwo przyszłości. Fikcja i rzeczywistość, Orgmasz, Warszawa 2004.

7 J. Machaczka, Zarzq̨dzanie rozwojem organizacji. Czynniki, modele, strategia, diagnoza, Wydawnictwo Naukowe PWN, Warszawa 1998.

8 S.L. Goldman i wsp., $21^{\text {st }}$ Century Manufacturing Enterprises Strategy: An Industry-led View, lacocca Institute, Bethlehem 1991; R. Dove, Response Ability: the Language, Structure, and Culture of the Agile Enterprise, Wiley, New York 2001.

9 S.L. Goldman, R. Nagel, K. Preiss, Agile competitors and virtual organizations, Van Nostrand Reinhold, New York 1995; H. Sharifi, Z. Zhang, Agile manufacturing in practice - Application of a methodology, „International Journal of Operations \& Production Management" 2001, vol. 21, no. 5/6, s. 772-794; Y. Yusuf i wsp., Agile supply chain capabilities: determinants of competitive objectives, „European Journal of Operational Research” 2004, vol. 159, no. 2, s. 379-392; C.A. Yauch, Measuring agility: combining organizational success and environmental turbulence, „International Journal of Agile Manufacturing” 2005, vol. 8, no. 2, s. 29-37; H. Sharifi, H.S. Ismail, I. Reid, Achieving agility in supply chain through simultaneous 'design of' and 'design for' supply chain, „Journal of Manufacturing Technology Management" 2006, vol. 17, no. 8, s. 1078-1098; C.A. Yauch, Measuring agility as a performance outcome, „Journal of Manufacturing Technology Management” 2011, vol. 22, issue 3, s. 384-404; J. Katkowska, H. Włodarkiewicz-Klimek, The susceptibility of organizations' potential on identifying the opportunities in the knowledge based-economy, Robot Motion and Control (RoMoCo), 10 $0^{\text {th }}$ International Workshop, IEEE Conference Publications, Poznań 2015, s. 207-212. 
dlatego, że otoczenie przedsiębiorstwa (np. produkującego mikrobusy i autobusy) jest zmienne i nieprzewidywalne ${ }^{10}$.

W zwinności organizatorskiej procesów wytwarzania istotną rolę odgrywa przede wszystkim dążenie do doskonałości, określające standardy wytwarzania na poziomie nazywanym klasą światową (World Class Manufacturing). Termin „klasa światowa” wprowadzony został ${ }^{11}$ w celu opisania konkurencyjnych zdolności eksportowych rozwiniętych przez japońskie i niemieckie przedsiębiorstwa. Zdolności te dotyczyły kilku dobrych praktyk obejmujących rozwój siły roboczej, rozwój grupy zarządzającej o kompetencjach technicznych, rywalizację za pomocą jakości, pobudzanie współuczestnictwa pracowników i inwestowanie w najnowocześniejsze wyposażenie. World Class Manufacturing to kompleksowe podejście umożliwiające osiąganie doskonałych wyników przez ciągłe ich poprawianie, zaangażowanie wszystkich poziomów i funkcji organizacji oraz przyjęcie zasad Total Quality Management, Lean Management i „zintegrowanej fabryki”12.

\section{Inteligentne wyzwania nieefektywnej algorytmizacji}

Wnioskowanie algorytmiczne w odniesieniu do problemu elastyczności i zwinności technologii i organizacji procesów wytwarzania maszyn może być stosowane tylko w przypadku precyzyjnego zrozumienia i opisania tego problemu (istnieje wiedza pozwalająca na jego zamodelowanie w postaci przesłanek technologicznych i organizacyjnych, jawnie zdefiniowanych i deterministycznych). Jeżeli przesłanek tych nie można precyzyjnie opisać w postaci matematycznej, ale na podstawie bezpośredniej obserwacji można wykryć pewne stałe wzorce zjawiska, to możliwa jest probabilistyczna algorytmizacja oparta na dedukcji. Złożony przypadek narastającej zmienności i nieprzewidywalności uwarunkowań otoczeniowych elastyczności i zwinności technologii oraz organizacji procesów wytwarzania maszyn oznacza jednak brak bezpośredniego, precyzyjnego określenia stałych wzorców przebiegu zjawiska. Rozwiązaniem takiej sytuacji, określanej mianem nieefektywnej

10 P.T. Kidd, Agile manufacturing: Key issues, [w:] P.T. Kidd, W. Karwowski (red.), Advances in agile manufacturing, IOS Press, Amsterdam 1994; Y. Yusuf, M. Sarhadi, A. Gunasekaran, Agile manufacturing: the drivers, concepts and attributes, „International Journal of Production Economics" 1999, no. 62, s. 33-43.

11 R.H. Hayes, S. C. Wheelwright, Restoring our Competitive Edge: Competing through Manufacturing, John Wiley, New York 1984.

12 T. Murino i wsp., World Class Manufacturing Implementation Model, Applied Mathematics in Electrical and Computer Engineering, Harvard, Cambridge 2012, s. 371-376. 
algorytmizacji, są podejścia indukcyjne oparte na metodach sztucznej inteligencji, stanowiących źródło ośmiu wspomnianych we wprowadzeniu narzędzi koncepcji Przemysłu 4.0. Narzędzia te zapewniają zdalną komunikację pomiędzy wytwórcami oraz użytkownikami maszyn a komponentem technologiczno-organizacyjnym. W obrębie tych metod dla problemów, które nie są efektywnie algorytmizowalne, tworzy się bowiem dwa rodzaje rozwiązań indukcyjnych. Należą do nich modele matematyczno-logiczne analizowanych problemów i ich implementacje w formie „inteligentnych” programów komputerowych (np. algorytmy genetyczne, metody logiki rozmytej) oraz ,inteligentne” programy komputerowe „samouczące się”, bazujące na modelach sieci neuronowych i sieci asocjacyjnych (np. sieci neuronowe, uczenie się maszyn, rozpoznawanie obrazów).

Rozwiązania te umożliwiają między innymi:

- lepsze dopasowanie procesów projektowania, wytwarzania i eksploatacji maszyn do wymogów rynku przez szybkie reagowanie na jego zmiany;

- skrócenie czasu projektowania i wprowadzania wytwarzanych maszyn na rynek;

- wytwarzanie maszyn spersonalizowanych, produkowanych zgodnie z preferencjami klientów, przy jednoczesnej minimalizacji kosztów produkcji oraz transformacji oferty produktowej i eksploatacyjnej dla klientów przez zbudowanie bliskich z nimi relacji;

- integrację wytwórczych procesów produkcyjnych, magazynowych i logistycznych maszyn z procesami ich użytkowania, obsługi eksploatacyjnej i utylizacji;

- lepszą kontrolę nad pełnym cyklem życia maszyny dzięki możliwości przekazywania danych monitorujących u klienta parametry diagnozowania stanu technicznego;

- łatwiejsze zarządzanie wytwarzaniem i eksploatacją maszyn w przypadku rozproszonych geograficznie oddziałów przedsiębiorstwa.

\section{Badanie eksploatacyjnych wyzwań inteligentnego wytwarzania maszyn}

Na bazie metody delfickiej ${ }^{13}$ opracowano ekspercką metodę przewidywania zależności określonych atrybutów eksploatacyjnych wyzwań inteligentnego wytwarzania mikrobusów i autobusów w praktyce od jedenastu wybranych kryteriów

13 H. Weihrich, H. Koontz, Management. A Global Perspective, McGraw-Hill, New York 1993; M. Trocki, Technika delficka, [w:] M. Stępkowski (red.), Nowe techniki organizatorskie, Wydawnictwo Naukowe PWN, Warszawa 1997; J. Kałkowska i wsp., Zarzqqdzanie strategiczne: metody analizy strategicznej z przykładami, Wydawnictwo Politechniki Poznańskiej, Poznań 2010. 
elastyczności i zwinności procesów ich wytwarzania. Przyjęto, że wnioskowanie o późniejszych (użytkowych i obsługowych oraz utylizacyjnych) ocenach eksploatacyjnych tych mikrobusów i autobusów na podstawie wcześniejszego spełnienia wymogów elastyczności i zwinności procesów ich wytwarzania ma charakter delfickiej relacji przewidującej przyszłość ${ }^{14}$.

Jedenaście kryteriów elastyczności i zwinności technologii i organizacji procesów wytwarzania mikrobusów i autobusów sformułowano następująco:

- Z1. Szybki wzrost zdolności produkcyjnych oraz produktywności dzięki wykorzystaniu (do potrzeb elastyczności i łatwości rekonfiguracji systemów wytwarzania) takich digitalizujących narzędzi jak integracja systemu, analiza Big Data, Internet rzeczy, wytwarzanie addytywne, chmura obliczeniowa i autonomiczne roboty, oraz dzięki własnemu montażowi, wspomaganemu przez procesy zewnętrzne i outsourcing.

- Z2. Maksymalizacja i doskonalenie wydajności maszyn i urządzeń technicznych (Total Productive Maintenance, Overall Equipment Effectiveness) oraz systematyczne i częste doskonalenie (Continuous Improvement) wytwarzania, z uwzględnieniem koncepcji Kaizen, Just in Time, 5S, SMED, FMEA, diagramu Ishikawy, zero zapasów, niskiego zaangażowania kapitału oraz prowadzenie eksperymentów symulacyjnych dzięki wykorzystaniu rzeczywistości rozszerzonej, integracji systemu, analizy Big Data, Internetu rzeczy, wytwarzania addytywnego, chmury obliczeniowej i autonomicznych robotów.

- Z3. Automatyzacja i robotyzacja procesów wytwarzania oraz ich integracja i autonomiczność, oparta na następujących narzędziach: autonomicznych robotach, rzeczywistości rozszerzonej, integracji systemu, analizie Big Data, Internecie rzeczy, wytwarzaniu addytywnym, chmurze obliczeniowej i cyberbezpieczeństwie, po uprzedniej reinżynierii tych procesów (Business Process Reengineering).

- Z4. Skuteczne zarządzanie czasem zadań i aktywności, ciągłe doskonalenie procesów (PDCA), wykorzystujące outsourcing oraz zasady zarządzania łańcuchem dostaw dzięki wykorzystaniu: rzeczywistości rozszerzonej, integracji systemu, analizy Big Data, Internetu rzeczy, wytwarzania addytywnego, chmury obliczeniowej i autonomicznych robotów.

- Z5. Wytwarzanie mikrobusów i autobusów o krótkim cyklu życia, ale niezawodnych w eksploatacji (w sytuacji awarii pojazdu natychmiastowa naprawa bądź wymiana na nowy) dzięki wykorzystaniu: integracji systemu, analizy Big Data, Internetu rzeczy, wytwarzania addytywnego, chmury obliczeniowej i autonomicznych robotów.

14 J. Katkowska, Podejście proeksploatacyjne w procesach powstawania pojazdów transportu publicznego, Wydawnictwo Politechniki Poznańskiej, Poznań 2018. 
- Z6. Satysfakcja klienta i jego lojalnościowe przywiązanie jako cel przedsiębiorstwa (systemy wytwarzania Mass Customization zintegrowane z jakością - Total Quality Management i szybką reakcją na potrzeby klienta), uzyskiwane przy narzędziowym wsparciu: rzeczywistości rozszerzonej, integracji systemu, analizy Big Data, Internetu rzeczy, wytwarzania addytywnego, chmury obliczeniowej i autonomicznych robotów.

- Z7. Utożsamianie się pracowników z interesem przedsiębiorstwa (Identity) oraz przejawianie chęci podnoszenia poziomu wiedzy i doskonalenie własnych kompetencji (Open Book Management), wspomagane narzędziowo przez: rzeczywistość rozszerzoną, integrację systemu, analizę Big Data, Internet rzeczy, chmurę obliczeniową i cyberbezpieczeństwo.

- Z8. Płaska struktura organizacyjna przedsiębiorstwa (upodmiotowienie i względna autonomia poziomu operacyjnego - Employee Empowerment); zarządzanie przez zespołowość działań i przywództwo (Leadership), oparte na partycypacji oraz podatności na zmiany i udoskonalenia, wspomagane narzędziowo przez: rzeczywistość rozszerzoną, integrację systemu, analizę Big Data, Internet rzeczy, chmurę obliczeniową i cyberbezpieczeństwo.

- Z9. Ukierunkowanie zarządzania kosztami przedsiębiorstwa na produktywność i jakość, oparte narzędziowo na: rzeczywistości rozszerzonej, integracji systemu, analizie Big Data, Internecie rzeczy i chmurze obliczeniowej.

- Z10. Elastyczność zakresu zmian procesów biznesowych, pozwalająca na wprowadzanie tych zmian szybko i ekonomicznie, wspomagana narzędziowo przez: rzeczywistość rozszerzoną, integrację systemu, analizę Big Data, Internet rzeczy, chmurę obliczeniową i cyberbezpieczeństwo.

- Z11. Spełnianie przez przedsiębiorstwo społecznego wymogu proekologicznego zarządzania firmą (zapewnienie z tego tytułu pracownikom przedsiębiorstwa osobistej i społecznej satysfakcji), oparte narzędziowo na: rzeczywistości rozszerzonej, integracji systemu, analizie Big Data, Internecie rzeczy, chmurze obliczeniowej i cyberbezpieczeństwie.

Z kolei siedem atrybutów eksploatacyjnych wyzwań inteligentnego wytwarzania mikrobusów i autobusów w praktyce określono następująco:

- E1. Skuteczność i efektywność funkcjonalna (w tym łatwość rozpoczęcia eksploatacji) oraz ekonomiczność użytkowania i obsługiwania.

- E2. Niezawodność i trwałość, odporność na wpływy atmosferyczne oraz uszkodzenia.

- E3. Bezpieczeństwo eksploatacyjne (w tym eliminacja przypadkowych uruchomień pojazdu, nieuprawnionego użytkowania, obsługiwania i możliwości umyślnego uszkodzenia). 
- E4. Ergonomiczność (w tym estetyczność ogólna pojazdu, skonfigurowanie i łatwość operowania, odporność na błędy operowania i chwilowe przeciążenia).

- E5. Ekologiczność eksploatacji.

- E6. Podatność diagnostyczna i obsługowa, naprawialność oraz podatność audytowa.

- E7. Podatność recyklingowa i utylizacyjna.

Praktyczna realizacja metody uzyskiwania quasi-morfologicznego efektu eksperckiej intuicji dwudziestu specjalistów polegała na zbieraniu ich odpowiedzi na siedemdziesiąt siedem pytań formułowanych na bazie schematu: „W jakim stopniu (w skali od 1 do 5, gdzie: 1 - brak zależności, 2 - zależność niewielka, 3 - zależność pośrednia, 4 - zależność istotna, 5 - zależność dominująca) określony atrybut eksploatacyjnych wyzwań inteligentnego wytwarzania mikrobusów i autobusów zależy (Twoim zdaniem) od konkretnego kryterium elastyczności i zwinności technologii i organizacji procesów tego wytwarzania?”.

Odpowiedzi dzieliło dwudziestu ekspertów (po dziesięciu praktyków i teoretyków): dwóch konstruktorów pojazdów, czterech technologów i organizatorów produkcji oraz eksploatacji, jeden organizator sprzedaży, jeden dostawca komponentów i mediów w procesach wytwarzania, jeden dostawca komponentów i mediów eksploatacyjnych dla użytkowników pojazdów, trzech użytkowników kierujących pojazdami, czterech użytkowników realizujących przeglądy i naprawy, trzech przedstawicieli pasażerów mikrobusów i autobusów oraz jeden likwidator pojazdów. Dla otrzymanych odpowiedzi ekspertów (z przedziału od 1 do 5) sporządzono wykres rozkładu tych opinii, wyznaczono medianę oraz określono przedziały międzykwartylowe. W obrębie każdego zestawu pytań eksperci zaopiniowali następnie (dla potrzeb rundy drugiej) wyliczone w ramach rundy pierwszej: medianę, przedziały międzykwartylowe oraz indywidualną odpowiedź z poprzedniej rundy. Biorąc pod uwagę taki zestaw informacji, eksperci po raz drugi odpowiedzieli na pytania $z$ rundy pierwszej. Jeżeli ich poprzednia odpowiedź leżała poza przedziałem międzykwartylowym i nowa odpowiedź również była spoza tego przedziału, to oczekiwano jej uzasadnienia. W ten sposób wymuszano przejście ekspertów niezdecydowanych i niemających odpowiednich argumentów do grupy stanowiącej większość, czyli do grupy, której odpowiedzi mieściły się w przedziałach międzykwartylowych. Proces badawczy obejmował cztery rundy opinii ekspertów (rysunek 2).

Dla badań prowadzonych na potrzeby tego artykułu przyjęto dychotomiczną postać relacji (istnienie zależności lub jej brak). Uznano, że o istnieniu relacji zależnościowej można mówić wówczas, gdy liczbowa wartość mediany wraz z dolną granicą przedziału międzykwartylowego przekracza dolny poziom zależności istotnej $(4,0)$. Wszystkie inne przypadki oznaczały brak takiej relacji zależnościowej. 


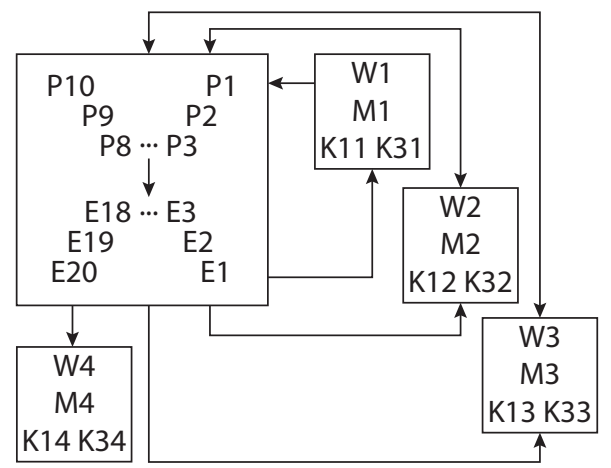

Rysunek 2. Proces badawczy obejmujący cztery rundy opinii ekspertów

Źródto: opracowanie własne na podstawie L. Pacholski, J. Kałkowska, Ł. Kiełbasa, Ergonomia wobec wyzwań masowości i globalizacji w produkcji, Wydawnictwo Politechniki Krakowskiej, Kraków 2019.

Quasi-morfologiczna analiza rezultatów badania relacji łączących siedem atrybutów eksploatacyjnych wyzwań inteligentnego wytwarzania maszyn z jedenastoma kryteriami elastyczności i zwinności technologii i organizacji procesów ich wytwarzania doprowadziła do konkluzji potwierdzającej przekroczenie poziomu zależności istotnej aż w czterdziestu jeden przypadkach badania siedemdziesięciu siedmiu potencjalnych relacji.

Gdyby próbować (na bazie uzyskanych wyników badań opinii ekspertów) tworzyć hierarchię najbardziej istotnych wyzwań inteligentnego wytwarzania maszyn, to niewątpliwie priorytetowo potraktować należałoby następujące:

- maksymalizację i doskonalenie wydajności maszyn i urządzeń technicznych oraz systematyczne i częste doskonalenie wytwarzania (z uwzględnieniem koncepcji Kaizen, Just in Time, 5S, SMED, FMEA, diagramu Ishikawy, zero zapasów, niskiego zaangażowania kapitału i prowadzenia eksperymentów symulacyjnych), dzięki wykorzystaniu: rzeczywistości rozszerzonej, integracji systemu, analizy Big Data, Internetu rzeczy, wytwarzania addytywnego, chmury obliczeniowej i autonomicznych robotów;

- orientację na satysfakcję klienta i jego lojalnościowe przywiązanie jako cel przedsiębiorstwa (systemy wytwarzania zintegrowane z jakością i szybką reakcją na potrzeby klienta), uzyskiwane przy narzędziowym wsparciu: rzeczywistości rozszerzonej, integracji systemu, analizy Big Data, Internetu rzeczy, wytwarzania addytywnego, chmury obliczeniowej i autonomicznych robotów.

Na kolejnym poziomie hierarchii zaleceń ulokować należałoby dwa kolejne wyzwania inteligentnego wytwarzania maszyn:

- działania na rzecz utożsamiania się pracowników z interesem przedsiębiorstwa (Identity) oraz przejawiania chęci podnoszenia poziomu wiedzy 
i doskonalenia własnych kompetencji, wspomagane narzędziowo przez: rzeczywistość rozszerzoną, integrację systemu, analizę Big Data, Internet rzeczy, chmurę obliczeniową i cyberbezpieczeństwo;

- dążenie do spłaszczania struktury organizacyjnej przedsiębiorstwa (upodmiotowienie i względna autonomia poziomu operacyjnego - Employee Empowerment), zarządzanie przez zespołowość działań i przywództwo (Leadership), oparte na partycypacji oraz podatności na zmiany i udoskonalenia, wspomagane narzędziowo przez: rzeczywistość rozszerzoną, integrację systemu, analizę Big Data, Internet rzeczy, chmurę obliczeniową i cyberbezpieczeństwo.

\section{Podsumowanie - konkluzje badawcze}

Reasumując badania prowadzone metodą delficką, należy wyeksponować pięć inteligentnych wyzwań przyszłości, wobec których stoją dziś technologia i organizacja procesów wytwarzania maszyn. Mogą być one wspomagane sztuczną inteligencją oraz narzędziowymi aplikacjami tworzącymi koncepcję Przemysłu 4.0. Wyzwania te są następujące:

- maksymalizacja i doskonalenie wydajności maszyn i urządzeń technicznych oraz systematyczne i częste doskonalenie procesów wytwarzania,

- orientacja na satysfakcję klienta i jego lojalnościowe przywiązanie jako cel przedsiębiorstwa (procesy wytwarzania zintegrowane z jakością oraz szybkie reagowanie na potrzeby klienta),

- działania na rzecz utożsamiania się pracowników z interesem przedsiębiorstwa (Identity) oraz przejawiania chęci podnoszenia poziomu wiedzy i doskonalenia własnych kompetencji,

- dążenie do spłaszczania struktury organizacyjnej przedsiębiorstwa przez upodmiotowienie i względną autonomię poziomu operacyjnego (Employee Empowerment),

- zarządzanie przez zespołowość działań i przywództwo (Leadership), oparte na partycypacji oraz podatności na zmiany i udoskonalenia.

Z kolei klasyczną metodę burzy mózgów Osborna, w wariancie Brain-netting, wykorzystano dodatkowo do zespołowego podsumowania kwestii uwarunkowań przełamania ludzkiego oporu wobec nieuchronnej zmiany, będącej następstwem inteligentnego wyzwania koncepcji Przemysłu 4.0. Prowadzony przez autorkę tego artykułu internetowy kwestionariusz wywiadu, z dostępem do dwudziestu ekspertów (uczestniczących we wcześniejszych badaniach metodą delficką), umożliwiał sukcesywne dopisywanie indywidualnych poglądów w przedmiotowej kwestii burzy mózgów. Pozwalało to także na bieżące śledzenie przez 
każdego z uczestników Brain-nettingu, rozbudowywanego banku opinii. Po tej sesji, określanej w ramach metody mianem twórczej, jej uczestnicy przeszli do kolejnych faz: weryfikacji opinii oraz wyboru podsumowujących uogólnień. Uogólnienia te obejmują następujące uwarunkowania:

- konieczne wydaje się dostosowywanie narzędzi inteligentnego wspomagania technologii i organizacji procesów wytwarzania maszyn do społecznego, biologicznego i ekonomicznego ekosystemu, w którym żyjemy, i zadbanie o to, by przy podejmowaniu decyzji dotyczących wybranych narzędzi koncepcji Przemysłu 4.0 uwzględniano możliwe ryzyka i potencjalne szkody, ponieważ entuzjaści inżynierii wiedzy czasami błędnie wyobrażają sobie „życzliwą” sztuczną inteligencję jako rozwiązującą nasze problemy, pomijając możliwe, szkodliwe rozwiązania i produkty;

- implementacja wybranych narzędzi koncepcji Przemysł 4.0 musi uwzględniać postulaty zrównoważonego rozwoju; celem zastosowań sztucznej inteligencji nie może być ona sama; odpowiedzialność za to, na co pozwala, oraz wykorzystywanie jej wybranych narzędzi ma bowiem wymiar społeczno-moralny; sztuczna inteligencja powinna sprzyjać poszerzaniu ludzkich możliwości, otwieraniu świata i wzbogacaniu życia, a także jednoczyć ludzi oraz doprowadzać do ich egalitaryzacji;

- inteligentne systemy technologii i organizacji procesów wytwarzania powinny, na bazie ich przejrzystości i odpowiedzialności, rozwijać zdolność tych systemów do ewolucji i ciągłej zmiany; demistyfikacja i budowa zaufania do wybranych narzędzi koncepcji Przemysłu 4.0 powinny służyć wyposażaniu systemów wytwarzania maszyn w nowe, rozwojowe umiejętności;

- dla efektywności i sukcesu osób oraz organizacji implementujących wybrane narzędzia koncepcji Przemysłu 4.0 kluczowe znaczenie mają umiejętności zrozumienia, analizowania, gromadzenia i doskonalenia danych, informacji i wiedzy, tak aby móc ocenić stopień możliwości w zakresie ich przeszukiwania i przetwarzania; oprócz profesjonalnej perfekcji w tym zakresie ważna jest pasja oraz doświadczenie związane z rozumieniem relacji wiążących ludzi i komponent technologiczny sprzętowych aplikacji koncepcji Przemysłu 4.0;

- w przypadku implementacji wybranych narzędzi koncepcji Przemysłu 4.0 musi być uwzględniona potrzeba zmiany klasycznych reguł interpersonalnego profesjonalizmu w związku z potrzebą umiejętności współdziałania ze „społecznością” manipulatorów, cobotów i autonomicznych robotów. 
Bibliografia

Ansoff H.I., Zarzq̨dzanie strategiczne, Polskie Wydawnictwo Ekonomiczne, Warszawa 1985.

Dove R., Response Ability: the Language, Structure, and Culture of the Agile Enterprise, Wiley, New York 2001.

Goldman S.L., Nagel R.N., Management, technology and agility: the Emergence of a new era in manufacturing, „International Journal of Technology Management” 1993, no. 8, s. 18-38.

Goldman S.L., Nagel R., Preiss K., Agile competitors and virtual organizations, Van Nostrand Reinhold, New York 1995.

Goldman S.L. Preiss K., Nagel R.N., Dove R., 21st Century Manufacturing Enterprises Strategy: An Industry-led View, lacocca Institute, Bethlehem 1991.

Hayes R.H., Wheelwright S. C., Restoring our Competitive Edge: Competing through Manufacturing, John Wiley, New York 1984.

Kałkowska J., Podejście proeksploatacyjne w procesach powstawania pojazdów transportu publicznego, Wydawnictwo Politechniki Poznańskiej, Poznań 2018.

Katkowska J., Włodarkiewicz-Klimek H., The susceptibility of organizations' potential on identifying the opportunities in the knowledge based-economy, Robot Motion and Control (RoMoCo), 10th International Workshop, IEEE Conference Publications, Poznań 2015.

Kałkowska J., Pawłowski E., Trzcielińska J., Trzcieliński S., Włodarkiewicz-Klimek H., Zarzqdzanie strategiczne: metody analizy strategicznej z przykładami, Wydawnictwo Politechniki Poznańskiej, Poznań 2010.

Kidd P.T., Agile manufacturing: Key issues, [w:] P.T. Kidd, W. Karwowski (red.), Advances in agile manufacturing, IOS Press, Amsterdam 1994.

Machaczka J., Zarzq̨dzanie rozwojem organizacji. Czynniki, modele, strategia, diagnoza, Wydawnictwo Naukowe PWN, Warszawa 1998.

Murino T., Naviglio G., Romano E., Guerra L., Revetria R., Mosca R., Cassettari L.C.A., World Class Manufacturing Implementation Model, Applied Mathematics in Electrical and Computer Engineering, Harvard, Cambridge 2012.

Nogalski B., Wybór paradygmatów zarządzania przedsiębiorstwem przyszłości, [w:] I.K. Hejduk (red.), Przedsiębiorstwo przyszłości. Fikcja i rzeczywistość, Orgmasz, Warszawa 2004.

Pacholski L., Kałkowska J., Kiełbasa Ł., Ergonomia wobec wyzwań masowości i globalizacji w produkcji, Wydawnictwo Politechniki Krakowskiej, Kraków 2019.

Sethi A.K., Sethi S.P., Flexibility in Manufacturing: A survey, „The International Journal of Flexible Manufacturing Systems" 1990, no. 2, s. 289-328.

Sharifi H., Zhang Z., Agile manufacturing in practice - Application of a methodology, „International Journal of Operations \& Production Management" 2001, vol. 21, no. 5/6, s. 772-794.

Sharifi H., Ismail H.S., Reid I., Achieving agility in supply chain through simultaneous 'design of' and 'design for' supply chain, „Journal of Manufacturing Technology Management” 2006, vol. 17 , no. 8, s. 1078-1098.

Sugalski W., Przemysł 4.0, PWC Polska, Warszawa 2018.

Trocki M., Technika delficka, [w:] M. Stępkowski (red.), Nowe techniki organizatorskie, Wydawnictwo Naukowe PWN, Warszawa 1997.

Trzcieliński S., Lean management a wirtualność przedsiębiorstwa, „Prace Naukowe Instytutu Organizacji i Zarządzania Politechniki Wroctawskiej” 2003, t. 73, nr 23, s. 291-306.

Trzcieliński S., Zwinne przedsiębiorstwo, Wydawnictwo Politechniki Poznańskiej, Poznań 2011. Weihrich H., Koontz H., Management. A Global Perspective, McGraw-Hill, New York 1993.

Yauch C.A., Measuring agility as a performance outcome, „Journal of Manufacturing Technology Management" 2011, vol. 22, issue 3, s. 384-404. 
Yauch C.A., Measuring agility: combining organizational success and environmental turbulence, „International Journal of Agile Manufacturing” 2005, vol. 8, no. 2, s. 29-37.

Yusuf Y., Sarhadi M., Gunasekaran A., Agile manufacturing: the drivers, concepts and attributes, „International Journal of Production Economics” 1999, no. 62, s. 33-43.

Yusuf Y., Gunasekaran A., Adeleye E.O., Sivayoganathan K., Agile supply chain capabilities: determinants of competitive objectives, „European Journal of Operational Research” 2004, vol. 159, no. 2, s. 379-392.

Zhang Z., Sharifi H., A methodology for achieving agility in manufacturing organizations, „International Journal of Operations and Production Management" 2000, vol. 20, no. 4, s. 496-513.

\section{Streszczenie}

Inteligentne aspekty wyzwań, przed którymi staną w niedalekiej przyszłości technologia i organizacja wytwarzania maszyn (mikrobusy i autobusy), dotyczą adaptacyjnego rozumienia, uczenia się oraz wykorzystywania posiadanej wiedzy i umiejętności w zmiennych uwarunkowaniach eksploatacyjnych. Turbulentność i nieprzewidywalność tych uwarunkowań są źródłem zwinnościowych problemów, które nie są efektywnie algorytmizowalne. Ich rozwiązywanie wymaga korzystania z ośmiu digitalizujących narzędzi koncepcji Przemysłu 4.0. Prezentowane w artykule badania nad tytułowymi wyzwaniami wykorzystują dwa zestawy metod heurystycznych: metodę delficką i jej quasi-morfologiczny efekt oraz kompleksową burzę mózgów. Konkluzje badawcze podkreślają między innymi wymóg zmiany klasycznych reguł organizatorskiego profesjonalizmu, ryzykologiczne wyzwania zrównoważonego ekosystemu oraz potrzebę „demistyfikacji” inteligentnych systemów.

Słowa kluczowe: technologia i organizacja wytwarzania, Przemysł 4.0

\section{Intelligent challenges of technology and organization of machine manufacturing processes}

\section{Abstract}

Intelligent aspects of challenges facing the technology and organization of machines production in the near future (microbuses and buses) relate to adaptive understanding, learning and the use of knowledge and skills in changing operational conditions. The turbulence and unpredictability of these conditions are a sources of agility problems that are not effectively algorithmizable. Solving them requires the use of eight digitizing challenges of the Industry 4.0. The research presented in the article uses two sets of heuristic methods: the Delphi method and its quasi-morphological effect as well as comprehensive brainstorming. Research conclusions emphasize, among others, the requirement of changing the classic rules of organizational professionalism, the risk-related challenges of a sustainable ecosystem as well as the need to "demystify" of intelligent systems.

Keywords: technology and organization of production, Industry 4.0 